This article is licensed under the Creative Commons Attribution-NonCommercial 4.0 International License (CC BY-NC) (http://www.karger.com/Services/OpenAccessLicense). Usage and distribution for commercial purposes requires written permission.

\title{
Diffuse Dermal Angiomatosis of the Breast: A Distinct Entity in the Spectrum of Cutaneous Reactive Angiomatoses - Clinicopathologic Study of Two Cases and Comprehensive Review of the Literature
}

\author{
Jörg Galambos ${ }^{a} \quad$ Claudia Meuli-Simmen ${ }^{b} \quad$ Regula Schmid $^{c}$ \\ Lisa S. Steinmann ${ }^{d}$ Werner Kempf ${ }^{a}$ e \\ ${ }^{a}$ Kempf und Pfaltz Histologische Diagnostik, Zurich, Switzerland; ${ }^{b} \mathrm{Clinic}$ of Hand, \\ Reconstructive, and Plastic Surgery, Kantonsspital Aarau, Aarau, Switzerland; \\ 'Dermatologie am Bahnhofplatz, Baden, Switzerland; ${ }^{\mathrm{d}}$ Hautpraxis, Luzern, Switzerland; \\ ${ }^{\mathrm{e}}$ Department of Dermatology, University Hospital Zurich, Zurich, Switzerland
}

\section{Keywords}

Diffuse dermal angiomatosis - Diffuse dermal angiomatosis of the breast - Cutaneous reactive angiomatosis $\cdot$ Reactive angioendotheliomatosis

\begin{abstract}
Diffuse dermal angiomatosis (DDA) is a rare reactive angioproliferation in the skin and considered to be a subtype in the group of cutaneous reactive angiomatoses. DDA is clinically characterized by livedoid patches and plaques with tender ulceration. Its histologic features are a reactive diffuse proliferation of bland endothelial cells and pericytes within the dermis, forming small capillary vessels. Previously described cases of DDA most commonly involved
\end{abstract}


Galambos et al.: Diffuse Dermal Angiomatosis of the Breast: A Distinct Entity in the Spectrum of Cutaneous Reactive Angiomatoses

the limbs and were associated with a wide spectrum of predisposing comorbidities, especially advanced atherosclerotic vascular disease and arteriovenous fistula. However, several cases of DDA of the breast (DDAB) have been reported in recent years. In this study we present 2 additional patients with DDAB and review all 36 cases of DDAB published in the literature. We describe the clinical and histopathologic characteristics, hypothesized pathogenetic mechanisms, and predisposing conditions of this rare skin disorder and discuss treatment options. The breast is a more commonly involved site of DDA than previously believed. DDAB typically occurs in middle-aged women and is associated with macromastia, overweight or obesity, and probably smoking. Predisposing comorbid conditions differ from those of DDA involving other parts of the body, making DDAB a unique clinicopathologic entity in the spectrum of cutaneous reactive angiomatoses. Currently there is no consensus on the best therapeutic approach. Isotretinoin and other medical therapies have been used with limited success. Breast reduction surgery appears to be a viable treatment option for DDAB in women with macromastia and might provide definitive healing.

(C) 2017 The Author(s)

Published by S. Karger AG, Basel

\section{Introduction}

Diffuse dermal angiomatosis (DDA) is a rare skin condition and characterized by a benign, reactive diffuse proliferation of capillary vessels within the dermis due to tissue hypoxia. Originally described in 1994 by Krell et al. [1], DDA is regarded as a variant within the group of cutaneous reactive angiomatoses. Clinically, DDA presents with slow-growing, reticulated erythematous to violaceous or purpuric patches and indurated plaques with vessel prominence, complicated by tender shallow ulceration. DDA was previously thought to involve mainly the limbs, especially the lower extremities in peripheral artery disease and the forearms secondary to an iatrogenic arteriovenous shunt for chronic hemodialysis. However, several women with exquisite breast involvement have been reported. Herein, we present an additional 2 women with DDA of the breast (DDAB) and review the 36 cases previously published in the medical literature. Data for the review were retrieved from a PubMed search between 1994 and 2016 (terms: diffuse dermal angiomatosis, diffuse dermal angiomatosis of the breast, cutaneous reactive angiomatosis, reactive angioendotheliomatosis).

\section{Case Reports}

\section{Patient 1}

A 51-year-old woman presented with slowly enlarging, reticulated erythematous to purple patches with tender ulceration and bleeding on her right breast of 2.5 years' duration (Fig. 1a, b). Her medical history was significant for hypertension without cardiovascular disease for which she was maintained on losartan and hydrochlorothiazide. She was a current smoker with a 72-pack-year history, obese (class II, BMI 35.0), and had large pendulous breasts.

A biopsy was performed since angiosarcoma was suspected. The biopsy specimen of lesional skin revealed diffuse proliferation of bland endothelial cells between collagen bundles 
Galambos et al.: Diffuse Dermal Angiomatosis of the Breast: A Distinct Entity in the Spectrum of Cutaneous Reactive Angiomatoses

in the upper and middle dermis (Fig. 2a), forming small capillary vessels (Fig. 3a). These cells were immunoreactive for CD31 (Fig. 2b), CD34, and ERG (Fig. 3b), but not for D2-40, and were surrounded by $\alpha$-smooth muscle actin ( $\alpha$-SMA)-positive pericytes (Fig. 3c).

A hypercoagulability workup was not performed. The patient was started on a regimen of isotretinoin at a dose of $40 \mathrm{mg}$ daily. During the course of treatment, liver enzymes and LDL cholesterol became abnormally elevated. No substantial improvement was noted after a 3 -month course of isotretinoin, although the patient managed to lose weight $(20 \mathrm{~kg})$ and changed her smoking habits (from 2 packs to half a pack of cigarettes daily). Unbearable pain due to ulceration could only be controlled by the use of opiates. The patient finally underwent bilateral reduction mammaplasty with complete excision of the DDA areas (with the removal of 721 and $713 \mathrm{~g}$ of tissue respectively from each breast). Follow-up 4.5 months post operation showed an acceptable cosmetic result (Fig. 1c), with no recurrence of the condition in the following 2.5 years.

\section{Patient 2}

A 52-year-old woman presented with a reticulated erythema and erosions on the underside of the right breast of 6 months' duration. She had noted similar changes starting also on the left breast. Previous therapy with different steroid creams did not improve the condition. Her medical history was significant for hypertension without cardiovascular disease and psoriasis. She was maintained on losartan and pantoprazole. She was a current smoker with a 82-pack-year history, obese (class I, BMI 34.7), and had large pendulous breasts. The pathologic findings of a biopsy specimen of involved skin was consistent with DDA.

The patient was informed about the potential benefits of changing her smoking habits for this particular condition and in general. With the smoking cessation aid varenicline she managed to quit smoking completely. Subsequently she considerably gained weight and the condition got even worse. Multiple therapeutic agents including topical antibiotics and steroids, hyaluronic acid and silver dressings, and astringents did not result in clinical improvement. She eventually underwent bilateral reduction mammaplasty with excision of DDA areas (with the removal of 1,550 and 1,548 $\mathrm{g}$ of tissue respectively from each breast). The first follow-up 3 months post operation showed a satisfying cosmetic result without recurrence of DDA.

\section{Discussion}

DDA has been recognized as a distinct variant of cutaneous reactive vascular proliferations in 1994 [1]. In 2001 the first case involving the breast in a woman was published by McLaughlin et al. [2], followed by only few published case reports and small case series in the English language literature until 2014 (a total of 14 cases). Only in 2015 was a larger series of 22 cases with breast involvement reported by Reusche et al. [3], making the breast probably the most commonly involved site of DDA. DDAB is usually bilateral and exclusively described in women, aged between 20 and 62 in all reports (mean age 46.6 years). Table 1 shows a summary of the 36 previously reported and our 2 additional cases.

DDA is regarded as a subtype within the spectrum of cutaneous reactive angiomatoses. The umbrella term "cutaneous reactive angiomatoses" was introduced by Rongioletti and 
Rebora [4] in 2003 to describe a reactive hyperplasia of endothelial cells and pericytes emerging in different clinical settings with variable clinical aspect. Histologically, cutaneous reactive angiomatosis can show an intravascular, an extravascular diffuse, or an extravascular lobular pattern, and encompasses three major subtypes: intravascular reactive angioendotheliomatosis, diffuse reactive angioendotheliomatosis (= DDA), and acroangiodermatitis (= pseudo-Kaposi sarcoma), all of them pathogenetically sharing tissue hypoxia due to different causes (Table 2). Intravascular and diffuse reactive angioendotheliomatosis, which have similar risk factors and pathogenetic mechanisms in common, possibly represent a morphologic spectrum or different stages of the same neoangiogenic process. "Intravascular histiocytosis" was originally also classified as cutaneous reactive angiomatosis [4]. Although the accumulation of histiocytes might be accompanied by endothelial hyperplasia with folding of endothelial strands into the lumina, this condition differs from other cutaneous reactive angiomatoses by the lymphatic nature of the affected vessels [5]. Therefore, this condition was renamed "intralymphatic histiocytosis" and should possibly be excluded from the cutaneous reactive angiomatoses in the stricter sense, invariably involving only blood vessels.

A wide spectrum of predisposing comorbid conditions have been associated with DDA in other body parts than the breast, such as advanced atherosclerotic vascular disease [610], iatrogenic arteriovenous fistula in the setting of chronic hemodialysis [11, 12], monoclonal gammopathy $[13,14]$, and the administration of trabectedin and pegfilgrastim in the context of liposarcoma in 1 case [15]. Cardiovascular risk factors, atherosclerotic vascular disease, and monoclonal gammopathy have also been described in association with DDAB. In 2 of the previously reported cases an underlying vaso-occlusive process directly responsible for DDAB could be identified, with stenosis of the subclavian artery due to a peripheral artery disease [16] and Takayasu arteritis [17], respectively. A monoclonal gammopathy was associated with DDAB in 1 case [18]. Moreover, an underlying hypercoagulable state was found in 1 case with positive testing for antiphospholipid antibodies [19] and suspected but not confirmed in 1 other case [17]. However, all cases reported in the latest and largest series of DDAB lacked a history of relevant associated diseases [3]. With the exception of hypertension in both our patients, no other comorbidities were associated in the presented 2 additional cases of DDAB. The most constant predisposing conditions for DDAB seem to be large pendulous breasts (in $75.0 \%$ of all reported cases, in 5 cases with a history of breast reduction surgery), overweight or obesity (in $96.6 \%$ of all reported cases), and smoking (current smokers and former smokers in all reported cases: 43.2 and $21.6 \%$, respectively).

A DDA-like reactive proliferation of capillary vessels is found in the dermis adjacent to necrotizing ulcers in patients with calciphylaxis [14, 20,21]. Calciphylaxis, also known as calcific uremic arteriolopathy, typically involves fat-rich areas such as the abdominal wall, thigh, buttocks, and also large breasts. Characterized by calcification, fibrointimal hyperplasia, and microthrombosis of dermal and subcutaneous small arteries and arterioles, most commonly in the setting of end-stage renal disease, cutaneous necrosis in calciphylaxis has critical tissue hypoxia in common with DDA. It is not clear whether DDA-like vascular proliferation precedes tissue necrosis resulting from low-grade ischemia or whether it is a secondary response to the frank ischemia in calciphylaxis [21].

Characteristic histologic features are a diffuse proliferation of endothelial cells and pericytes interstitially arranged between the collagen bundles within the papillary and reticular 
Galambos et al.: Diffuse Dermal Angiomatosis of the Breast: A Distinct Entity in the Spectrum of Cutaneous Reactive Angiomatoses

dermis, forming small capillary vessels with barely visible lumina. Endothelial cells may be spindle-shaped or exhibit a vacuolated cytoplasm as an expression of primitive vascular differentiation, but show no cytologic atypia or mitoses. Immunohistochemically, proliferating cells express endothelial markers such as CD31, CD34, and ERG (a member of the ETS family of transcription factors), but not D2-40/podoplanin or other antigens that characterize lymphatic differentiation of endothelia. These newly formed vessels are surrounded by $\alpha$-SMA-positive pericytes, highlighting the features of fully functional blood capillaries and the benign nature of this proliferation.

The pathogenesis of DDA is incompletely understood. The neoangiogenesis characteristic of DDA is most likely the consequence of ischemia with tissue hypoxia due to (subtotally) occlusive or inflammatory vascular processes. The hypothesis is that tissue hypoxia leads to un upregulation of proangiogenic cytokines. Under the stimulus of vascular endothelial growth factor and other angiogenetic factors, endothelial cells proliferate in an attempt to form new vessels in order to restore the diminished blood circulation and tissue oxygenation, respectively. Tissue hypoxemia in DDAB is probably the result of subclinical torsion, compression, and increased venous hydrostatic pressure related to the macromastia. An impairment in pulmonary function due to obstructive sleep apnea syndrome and/or obesity hypoventilation syndrome may contribute to the local tissue hypoxia in obese women. Moreover, excess weight against the chest related to macromastia might impair chest wall mechanics as well. Endothelial dysfunction, inflammatory vascular processes, and a shift towards a procoagulant state due to insulin resistance [22] and smoking [23] possibly aggravate the relative ischemia. Underlying hypercoagulability seems to play a minor pathogenetic role, as in only 1 reported case antiphospholipid antibodies were present [19]. In 2 cases of DDA, linear and granular deposits of immunoreactants along endothelial cells and at the dermal-epidermal junction in lesional skin were observed [13]. The pathogenetic role of these deposits is unsettled and needs to be elucidated in further studies.

Due to the diffuse, "pseudoangiosarcomatous" dissecting growth pattern, the histopathologic differential diagnosis of DDAB principally includes well-differentiated cutaneous angiosarcoma, postradiation atypical vascular lesion, patch/plaque-stage Kaposi sarcoma, as well as benign lymphangioendothelioma and lymphangiomatosis, all of which share some of the clinical findings of DDAB. Irregular vascular channels, the lack of an outer layer of $\alpha$-SMA-positive pericytes, as well as atypia, mitoses, and multilayering of endothelial cells differentiate cutaneous angiosarcoma from DDAB. D2-40/podoplanin expression of endothelial cells and the lack of surrounding $\alpha$-SMA-positive pericytes help distinguish postradiation atypical vascular lesion, benign lymphangioendothelioma, and lymphangiomatosis from DDAB, confirming the lymphatic nature of these vascular proliferations. Frank spindling of cells, irregular slit-like lumen formation, the so called "promontory sign," an inflammatory infiltrate, and positive immunostaining for HHV-8 distinguish Kaposi sarcoma from DDAB. Calcification and microthrombosis of dermal and subcutaneous vessels as well as extensive cutaneous necrosis differentiate DDA-like vascular proliferation in calciphylaxis from DDA in the stricter sense.

The management of DDAB requires an improvement of the underlying relative ischemia and tissue hypoxemia. A clinical evaluation of the patient's vascular status in order to exclude occlusion of the subclavian artery is recommended, especially in women with cardiovascular risk factors. In the 2 reported cases of subclavian artery occlusion, revascularization 
Galambos et al.: Diffuse Dermal Angiomatosis of the Breast: A Distinct Entity in the Spectrum of Cutaneous Reactive Angiomatoses

with stent placement resulted in substantial improvement [16, 17]. A workup to exclude calciphylaxis involving the breasts or a hypercoagulable state is advisable in patients with reduced kidney function, end-stage kidney failure, or a history of thromboembolic events. The first therapeutic approach is focused on education about weight control and smoking cessation as well as the control of other cardiovascular risk factors such as hypertension or hyperlipidemia, if present. Complete healing was observed in all 3 cases reported by SanzMotilva et al. [18] within 12 months after smoking cessation without any other specific therapy. In one of our cases, smoking cessation had no positive effect. Improvement was noticed with isotretinoin therapy in 6 previously reported patients $[2,3,16,17,24]$, with recurrence of the condition in 2 cases when treatment was discontinued. In one of our women isotretinoin treatment was not effective. Clinical improvement has mainly been attributed to antiangiogenic effects of 13-cis-retinoic acid and other retinoids [2, 25]. Other anecdotal medical therapies with pentoxifylline, aspirin, nifedipine, or oral corticosteroids have been attempted with equivocal success. Three previously reported women had a successful outcome following breast reduction surgery $[3,26]$. Bilateral reduction mammaplasty was also effective in both of our 2 patients, without recurrence after a follow-up of 30 months and 3 months, respectively. DDAB developed in 5 previously reported women with macromastia following breast reduction surgery $[3,17,24]$. Taking into consideration the strong association with large pendulous breasts and the hypothesized pathogenesis, reduction mammaplasty appears to be a viable treatment option of DDAB in women with macromastia.

Breast involvement of DDA is much more common than previously believed, the breast presumably being the most commonly involved site in DDA. DDAB can be regarded as a unique clinicopathologic entity within the spectrum of cutaneous reactive angiomatoses, since the clinical setting and predisposing factors differ from DDA involving other parts of the body. DDAB, typically occurring in middle-aged women, is associated with macromastia, overweight or obesity, and probably cigarette smoking. Thus, weight control and control of tobacco use are important supporting measures in the management of this destressing condition. Isotretinoin and other medical therapies have been used with limited success, without complete resolution in the majority of cases. Breast reduction surgery was effective in 5 women, including our 2 cases, and should therefore be evaluated in patients who fail conservative therapy. The benefit of surgical management of DDAB, which might provide definitive healing, has to be evaluated in further studies with long-term follow-up.

\section{Statement of Ethics}

The authors have no ethical conflicts to disclose.

\section{Disclosure Statement}

The authors have no conflicts of interest to disclose. 
Galambos et al.: Diffuse Dermal Angiomatosis of the Breast: A Distinct Entity in the Spectrum of Cutaneous Reactive Angiomatoses

\section{References}

-1 Krell JM, Sanchez RL, Solomon AR: Diffuse dermal angiomatosis: a variant of reactive cutaneous angioendotheliomatosis. J Cutan Pathol 1994;21:363-370.

2 McLaughlin ER, Morris R, Weiss SW, Arbiser JL: Diffuse dermal angiomatosis of the breast: response to isotretinoin. J Am Acad Dermatol 2001;45:462-465.

-3 Reusche R, Winocour S, Degnim A, Lemaine V: Diffuse dermal angiomatosis of the breast: a series of 22 cases from a single institution. Gland Surg 2015;4:554-560.

4 Rongioletti F, Rebora A: Cutaneous reactive angiomatoses: patterns and classification of reactive vascular proliferation. J Am Acad Dermatol 2003;49:887-896.

5 Requena L, El-Shabrawi-Caelen L, Walsh SN, Segura S, Ziemer M, Hurt MA, Sangüeza OP, Kutzner H: Intralymphatic histiocytosis. A clinicopathologic study of 16 cases. Am J Dermatopathol 2009;31:140151.

Kimyai-Asadi A, Nousari HC, Ketabchi N, Henneberry JM, Costarangos C: Diffuse dermal angiomatosis: a variant of reactive angioendotheliomatosis associated with atherosclerosis. J Am Acad Dermatol 1999;40:257-259.

Kim S, Elenitsas R, James WD: Diffuse dermal angiomatosis: a variant of reactive angioendotheliomatosis associated with peripheral vascular atherosclerosis. Arch Dermatol 2002;138:456-458.

Draper BK, Boyd AS: Diffuse dermal angiomatosis. J Cutan Pathol 2006;33:646-648.

Sriphojanart T, Vachiramon V: Diffuse dermal angiomatosis: a clue to the diagnosis of atherosclerotic vascular disease. Case Rep Dermatol 2015;7:100-106.

Crickx E, Saussine A, Vignon-Pennamen MD, Cordoliani F, Mouly F, Bagot M, Ryboyad M: Diffuse dermal angiomatosis associated with severe atherosclerosis: two cases and review of the literature. Clin Exp Dermatol 2015;40:521-524.

11 Requena L, Farina MC, Renedo G, Alvarez A, Yus ES, Sangueza OP: Intravascular and diffuse dermal reactive angioendotheliomatosis secondary to iatrogenic arteriovenous fistulas. J Cutan Pathol 1999;26:159-164.

-12 Sommer S, Merchant WJ, Wilson CL: Diffuse dermal angiomatosis due to an iatrogenic arteriovenous fistula. Acta Derm Venereol 2004;84:251-252.

13 Quatresooz P, Fumal I, Willemaers V, Cornil F, Piérard GE: Diffuse dermal angiomatosis. A previously undescribed pattern of immunoglobulin and complement deposits in two cases. Am J Dermatopathol 2006;28:150-154.

14 Ferreli C, Atzori L, Pinna AL, Pau M, Aste N, Ricotti C, Rongioletti F: Diffuse dermal angiomatosis: a clinical mimicker of vasculitis associated with calciphylaxis and monoclonal gammopathy. G Ital Dermatol Venereol 2015;150:115-121.

-15 Mayor-Ibarguren A, Gómez-Fernández C, Beato-Merino MJ, González-Ramos J, Rodríguez-Bandera AI, Herranz-Pinto P: Diffuse reactive angioendotheliomatosis secondary to the administration of trabectedin and pegfilgrastim. Am J Dermatopathol 2015;37:581-584.

16 Yang H, Ahmed I, Mathew V, Schroeter AL: Diffuse dermal angiomatosis of the breast. Arch Dermatol 2006;142:343-347.

17 Tollefson MM, McEvoy MT, Torgerson RR, Bridges AG: Diffuse dermal angiomatosis of the breast: clinicopathologic study of 5 patients. J Am Acad Dermatol 2014;71:1212-1217.

18 Sanz-Motilva V, Martorell-Calatayud A, Rongioletti F, Escutia-Muñoz B, López-Gómez S, RodríguezPeralto JL, Vanaclocha F: Diffuse dermal angiomatosis of the breast: clinical and histopathological features. Int J Dermatol 2014;53:445-449.

19 Pichardo RO, Lu D, Sangueza OP, Guitart J: What is your diagnosis? Diffuse dermal angiomatosis secondary to anticardiolipin antibodies. Am J Dermatopathol 2002;24:502-503. Prinz Vavricka BM, Barry C, Victor T, Guitart J: Diffuse dermal angiomatosis associated with calciphylaxis. Am J Dermatopathol 2009;31:653-657.

-21 Steele KT, Sullivan BJ, Wanat KA, Rosenbach M, Elenitsas E: Diffuse dermal angiomatosis associated with calciphylaxis in a patient with end-stage renal disease. J Cutan Pathol 2013;40:829-832.

22 Muniyappa R, Sowers JR: Role of insulin resistance in endothelial dysfunction. Rev Endocr Metab Disord 2013;14:5-12.

23 Messner B, Bernhard D: Smoking and cardiovascular disease: mechanisms of endothelial dysfunction and early atherogenesis. Arterioscler Thromb Vasc Biol 2014;34:509-515.

24 Adams BJ, Goldberg S, Massey HD, Kazuaki T: A cause of unbearably painful breast, diffuse dermal angiomatosis. Gland Surg 2012;1:132-135. 


\section{Case Reports in Dermatology}

Galambos et al.: Diffuse Dermal Angiomatosis of the Breast: A Distinct Entity in the Spectrum of Cutaneous Reactive Angiomatoses

-25 Lingen MW, Polverini PJ, Bouck NP: Retinoic acid induces cells cultured from oral squamous cell carcinomas to become anti-angiogenic. Am J Pathol 1996;149:247-258.

26 Villa MT, White LE, Petronic-Rosic V, Song DH: The treatment of diffuse dermal angiomatosis of the breast with reduction mammaplasty. Arch Dermatol 2008;144:693-694.
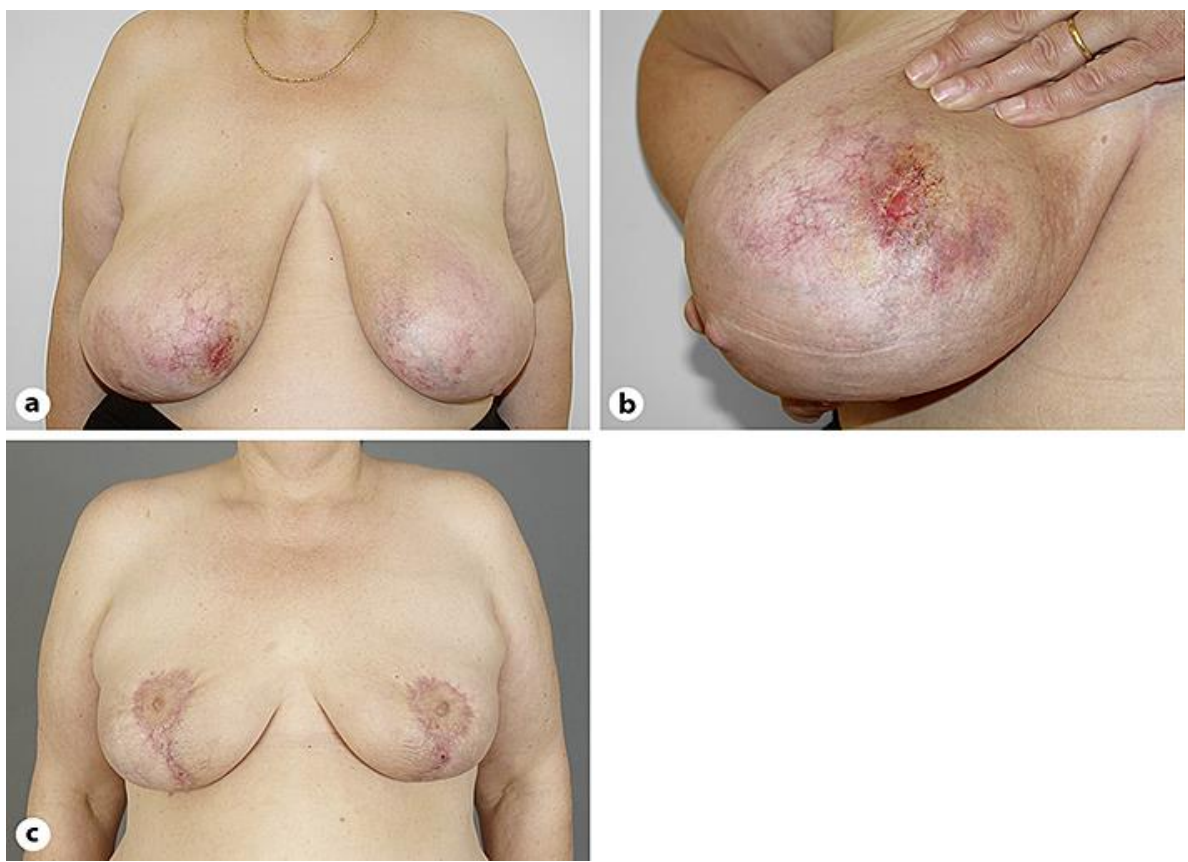

Fig. 1. Diffuse dermal angiomatosis of the breast. a Reticulated erythematous to violaceous patches involving both breasts, with ulceration on the right side. b Detail with prominent vessels surrounding the lesion. c Follow-up 4.5 months after bilateral reduction mammaplasty with no recurrence of the condition. 


\section{Case Reports in Dermatology}

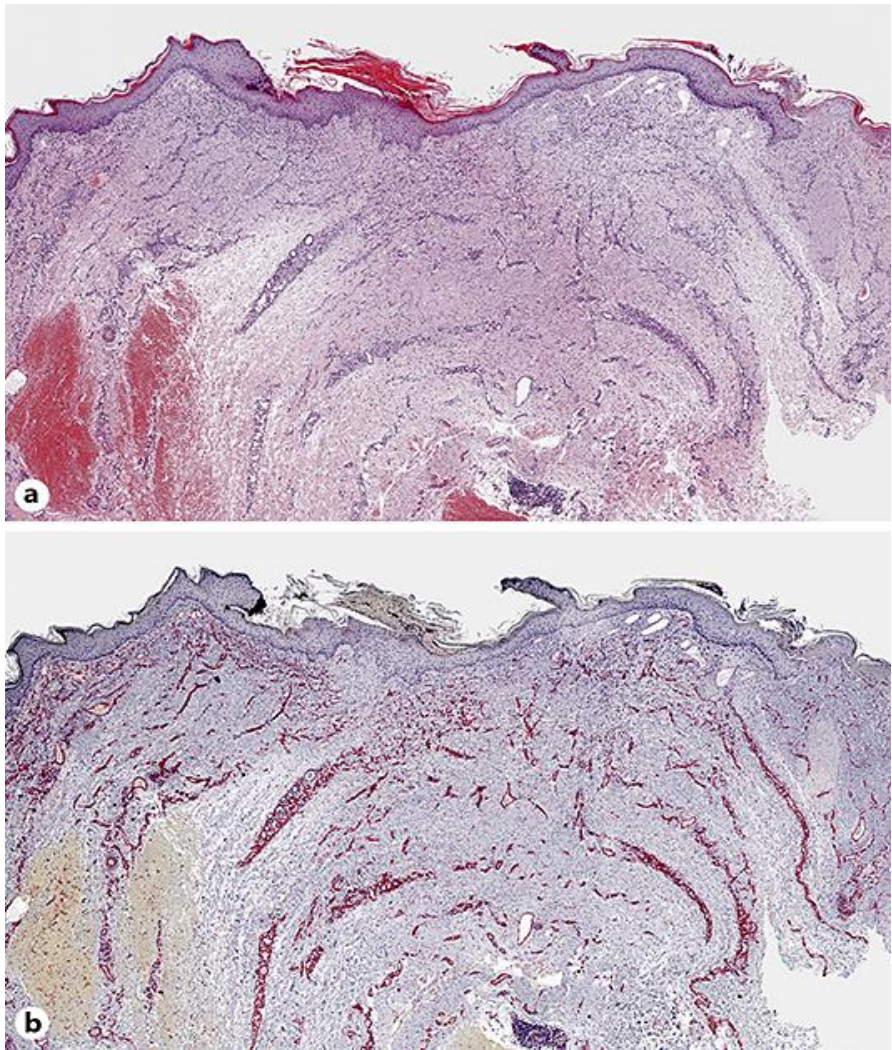

Fig. 2. Histology of diffuse dermal angiomatosis. a Diffuse proliferation of capillary vessels in the superficial and deep dermis between the collagen bundles, with characteristic shallow ulceration. b Strong expression of CD31 highlighting the endothelial nature of proliferating cells. a Hematoxylin-eosin stain. Original magnification: $\mathbf{a}, \mathbf{b} \times 40$. 


\section{Case Reports in Dermatology}
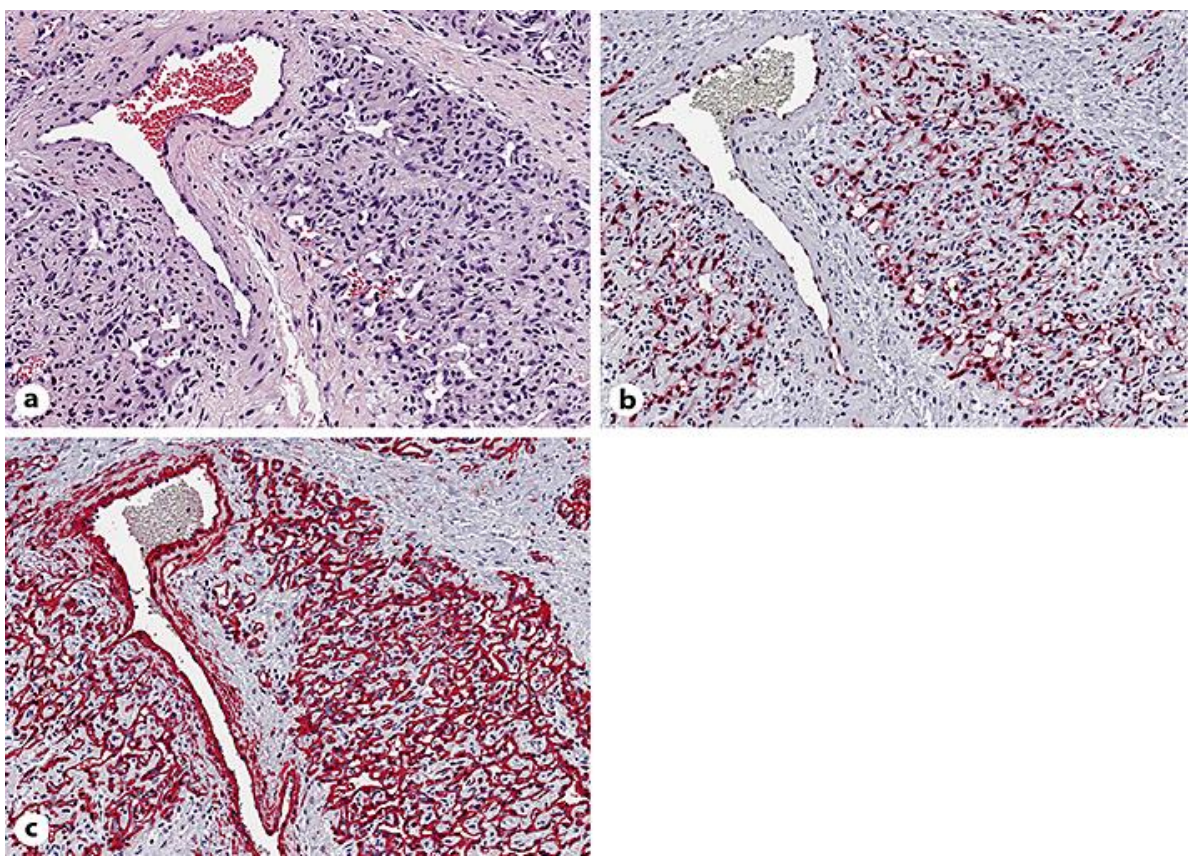

Fig. 3. a Dense proliferation of endothelial cells without nuclear atypia, forming capillary vessels with barely identifiable vascular lumina, surrounding a normal vessel. b Nuclear expression of ERG, a highly specific marker for vascular endothelium. c Newly formed capillary vessels show a normal anatomic architecture of blood vessels with an outer layer of $\alpha$-SMA-positive pericytes. a Hematoxylin-eosin stain. Original magnification: a-c $\times 200$. 
Galambos et al.: Diffuse Dermal Angiomatosis of the Breast: A Distinct Entity in the Spectrum of Cutaneous Reactive Angiomatoses

Table 1. Characteristics of reported women with DDA of the breast in the literature and of our 2 cases $^{1}$

\begin{tabular}{|c|c|c|c|c|c|c|c|}
\hline Reference & $\begin{array}{l}\text { No. of } \\
\text { patients/ } \\
\text { mean age, y }\end{array}$ & $\begin{array}{l}\text { Macromastia; } \\
\text { history of breast } \\
\text { reduction surgery }\end{array}$ & $\begin{array}{l}\text { Elevated } \\
\text { BMI }\end{array}$ & $\begin{array}{l}\text { Smoking } \\
\text { habits }\end{array}$ & Comorbidities & Management & Follow-up \\
\hline $\begin{array}{l}\text { McLaughlin et al. } \\
{[2], 2001}\end{array}$ & $1 / 28$ & $\begin{array}{l}\text { large pendulous } \\
\text { breasts }\end{array}$ & na & $\begin{array}{l}\text { current } \\
\text { smoker }\end{array}$ & no relevant medical history & isotretinoin $80 \mathrm{mg} /$ day & $\begin{array}{l}\text { dramatically improved after } \\
2 \text { months; patient lost to FU }\end{array}$ \\
\hline $\begin{array}{l}\text { Pichardo et al. } \\
{[19], 2002}\end{array}$ & $1 / 47$ & $\begin{array}{l}\text { large pendulous } \\
\text { breasts }\end{array}$ & na & na & IgM anticardiolipin antibodies & $\begin{array}{l}\text { low-dose aspirin and } \\
\text { pentoxifylline }\end{array}$ & $\begin{array}{l}\text { improved with aspirin and } \\
\text { pentoxifylline }\end{array}$ \\
\hline $\begin{array}{l}\text { Yang et al. [16], } \\
2006\end{array}$ & $1 / 53$ & na & na & $\begin{array}{l}\text { current } \\
\text { smoker }\end{array}$ & $\begin{array}{l}\text { hyperlipidemia, coronary artery disease, } \\
\text { peripheral artery disease with unilateral } \\
\text { subclavian artery occlusion }\end{array}$ & $\begin{array}{l}\text { isotretinoin } 40 \mathrm{mg} / \text { day; } \\
\text { subclavian artery } \\
\text { revascularization }\end{array}$ & $\begin{array}{l}\text { markedly improved } \\
\text { with isotretinoin; } \\
\text { completely resolved after } \\
\text { revascularization }\end{array}$ \\
\hline $\begin{array}{l}\text { Quatresooz et al. } \\
{[13], 2006}\end{array}$ & $1 / 46$ & na & obesity & $\begin{array}{l}\text { current } \\
\text { smoker }\end{array}$ & $\begin{array}{l}\text { hypertension, hyperlipidemia, unilateral } \\
\text { humeral artery thrombosis without } \\
\text { underlying hypercoagulable state }\end{array}$ & oral corticosteroids & $\begin{array}{l}\text { markedly improved with } \\
\text { oral corticosteroids }\end{array}$ \\
\hline $\begin{array}{l}\text { Villa et al. [26], } \\
2008\end{array}$ & $1 / 20$ & $\begin{array}{l}\text { large pendulous } \\
\text { breasts }\end{array}$ & overweight & $\begin{array}{l}\text { former } \\
\text { smoker }\end{array}$ & no relevant medical history & reduction mammaplasty & $\begin{array}{l}\text { completely resolved; no } \\
\text { recurrence } 4 \text { months PO }\end{array}$ \\
\hline $\begin{array}{l}\text { Adams et al. [24], } \\
2012\end{array}$ & $1 / 59$ & $\begin{array}{l}\text { large pendulous } \\
\text { breasts; reduction } \\
\text { mammaplasty }\end{array}$ & na & $\begin{array}{l}\text { current } \\
\text { smoker }\end{array}$ & $\begin{array}{l}\text { hypertension, hyperlipidemia, } \\
\text { cerebrovascular accident, COPD }\end{array}$ & isotretinoin $100 \mathrm{mg} /$ day & improved with isotretinoin \\
\hline $\begin{array}{l}\text { Sanz-Motilva et al. } \\
{[18], 2014}\end{array}$ & $\begin{array}{l}3 / 57.6 \\
(57-59)\end{array}$ & $\begin{array}{l}\text { large pendulous } \\
\text { breasts ( } 3 \text { ) }\end{array}$ & $\begin{array}{l}\text { overweight } \\
\text { (2) }\end{array}$ & $\begin{array}{l}\text { current } \\
\text { smokers } \\
(3)\end{array}$ & $\begin{array}{l}\text { hypertension, hepatic cirrhosis, basal } \\
\text { ganglia hematoma (1); monoclonal } \\
\text { gammopathy (1); breast cancer treated } \\
\text { with unilateral mastectomy and } \\
\text { lymphadenectomy, hepatic cirrhosis } \\
\text { due to hepatitis B treated with liver } \\
\text { transplant (1) }\end{array}$ & smoking cessation (3) & $\begin{array}{l}\text { completely resolved after } \\
6 \text { months (1) and } 12 \\
\text { months (2), respectively, } \\
\text { without additional specific } \\
\text { therapy }\end{array}$ \\
\hline $\begin{array}{l}\text { Tollefson et al. } \\
{[17], 2014}\end{array}$ & $\begin{array}{l}5 / 51 \\
(47-58)\end{array}$ & $\begin{array}{l}\text { large pendulous } \\
\text { breasts (5); } \\
\text { reduction } \\
\text { mammaplasty (3) }\end{array}$ & na & $\begin{array}{l}\text { current } \\
\text { smoker } \\
(1) ; \\
\text { former } \\
\text { smokers } \\
(2)\end{array}$ & $\begin{array}{l}\text { Takayasu arteritis with bilateral } \\
\text { subclavian artery occlusion and } \\
\text { secondary stroke, hypertension (1); } \\
\text { peripheral artery disease (1); multiple } \\
\text { thromboembolic events, but no } \\
\text { hypercoagulability found (1); no } \\
\text { relevant medical history except for } \\
\text { breast reduction surgery (2) }\end{array}$ & $\begin{array}{l}\text { subclavian artery } \\
\text { revascularization (1); } \\
\text { isotretinoin } 80 \mathrm{mg} / \text { day } \\
\text { (1) }\end{array}$ & $\begin{array}{l}\text { improved after } \\
\text { revascularization (1); } \\
\text { markedly improved with } \\
\text { isotretinoin (1) }\end{array}$ \\
\hline $\begin{array}{l}\text { Reusche et al. [3], } \\
2015\end{array}$ & $\begin{array}{l}22^{2} / 48.4 \\
(20-62)\end{array}$ & $\begin{array}{l}\text { large pendulous } \\
\text { breasts (13); } \\
\text { reduction } \\
\text { mammaplasty (1) }\end{array}$ & $\begin{array}{l}\text { overweight or } \\
\text { obesity }(22) ; \\
\text { obesity class II } \\
(15)\end{array}$ & $\begin{array}{l}\text { current } \\
\text { smokers } \\
(6) ; \\
\text { former } \\
\text { smokers } \\
\text { (5) }\end{array}$ & no relevant medical history (22) & $\begin{array}{l}\text { isotretinoin }^{3}(2) ; \\
\text { pentoxifylline (2); } \\
\text { pentoxifylline and } \\
\text { nifedipine (1); aspirin (1); } \\
\text { reduction mammaplasty (1); } \\
\text { mastectomy (1) }\end{array}$ & $\begin{array}{l}\text { improved with isotretinoin } \\
(2), \text { recurrence when } \\
\text { taken off therapy (2); } \\
\text { improved but not resolved } \\
\text { with pentoxifylline (2); } \\
\text { pentoxifylline and } \\
\text { nifedipine not effective (1); } \\
\text { improved but not resolved } \\
\text { with aspirin (1); completely } \\
\text { resolved after breast } \\
\text { surgery (2), no recurrence } \\
\text { after } 20 \text { months of FU }\end{array}$ \\
\hline Our patient 1 & $1 / 51$ & $\begin{array}{l}\text { large pendulous } \\
\text { breasts }\end{array}$ & $\begin{array}{l}\text { obesity class II } \\
\text { (BMI 35.0) }\end{array}$ & $\begin{array}{l}\text { current } \\
\text { smoker } \\
(72 \mathrm{PY})\end{array}$ & hypertension & $\begin{array}{l}\text { isotretinoin } 40 \mathrm{mg} / \mathrm{day} \text {; } \\
\text { bilateral reduction } \\
\text { mammaplasty with excision } \\
\text { of involved areas }\end{array}$ & $\begin{array}{l}\text { isotretinoin not effective; } \\
\text { completely resolved after } \\
\text { breast surgery; no } \\
\text { recurrence after } 4.5 \text { months } \\
\text { and } 2.5 \text { years of FU PO }\end{array}$ \\
\hline Our patient 2 & $1 / 52$ & $\begin{array}{l}\text { large pendulous } \\
\text { breasts }\end{array}$ & $\begin{array}{l}\text { obesity class I } \\
\text { (BMI 34.7) }\end{array}$ & $\begin{array}{l}\text { current } \\
\text { smoker } \\
(82 \mathrm{PY})\end{array}$ & hypertension & $\begin{array}{l}\text { smoking cessation; bilateral } \\
\text { reduction mammaplasty } \\
\text { with excision of involved } \\
\text { areas }\end{array}$ & $\begin{array}{l}\text { smoking cessation without } \\
\text { positive effect; completely } \\
\text { resolved after breast } \\
\text { surgery; no recurrence } \\
\text { after } 3 \text { months of FU PO }\end{array}$ \\
\hline
\end{tabular}

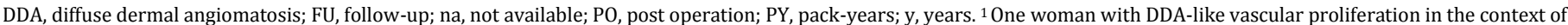

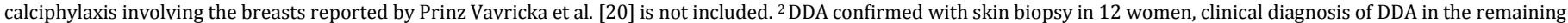
10 women. ${ }^{3}$ Dosage not available. 
Galambos et al.: Diffuse Dermal Angiomatosis of the Breast: A Distinct Entity in the Spectrum of Cutaneous Reactive Angiomatoses

Table 2. Major subtypes of cutaneous reactive angiomatoses (modified from Rongioletti and Rebora [4])

\begin{tabular}{|c|c|c|}
\hline & Associated conditions & Histopathologic findings \\
\hline $\begin{array}{l}\text { Intravascular } \\
\text { reactive } \\
\text { angioendo- } \\
\text { theliomatosis }\end{array}$ & $\begin{array}{l}\text { Cutaneous microvascular occlusion (e.g., emboli } \\
\text { in the setting of subacute bacterial endocarditis, } \\
\text { cholesterol emboli, monoclonal gammopathy, } \\
\text { monoclonal cryoglobulinemia, antiphospholipid } \\
\text { syndrome) } \\
\text { Arteriovenous shunts (chronic hemodialysis) } \\
\text { Infections (e.g., hepatitis) } \\
\text { Renal disease } \\
\text { Rheumatoid arthritis } \\
\text { Unusual residual lesion in certain cases of } \\
\text { leukocytoclastic vasculitis }\end{array}$ & $\begin{array}{l}\text { Proliferation of endothelial } \\
\text { cells within the lumina of } \\
\text { dilated preexisting blood } \\
\text { vessels } \\
\text { At different levels of the } \\
\text { dermis }\end{array}$ \\
\hline $\begin{array}{l}\text { Diffuse reactive } \\
\text { angioendo- } \\
\text { theliomatosis } \\
=\text { DDA }\end{array}$ & $\begin{array}{l}\text { Advanced atherosclerotic vascular disease } \\
\text { Arteriovenous shunts (chronic hemodialysis) } \\
\text { Monoclonal gammopathy } \\
\text { Antiphospholipid antibodies } \\
\text { Calciphylaxis (DDA-like vascular proliferation) }\end{array}$ & $\begin{array}{l}\text { Diffuse proliferation of } \\
\text { capillary vessels with narrow } \\
\text { lumina } \\
\text { Interstitially between the } \\
\text { collagen bundles within the } \\
\text { full thickness of the dermis }\end{array}$ \\
\hline $\begin{array}{l}\text { Acroangiodermatitis } \\
=\text { pseudo-Kaposi } \\
\text { sarcoma }\end{array}$ & & $\begin{array}{l}\text { Proliferation of thick-walled } \\
\text { capillary vessels in a lobular } \\
\text { pattern with patent, mostly } \\
\text { wide open lumina } \\
\text { Within the papillary dermis }\end{array}$ \\
\hline Mali type & Venous hypertension & \\
\hline $\begin{array}{l}\text { Steward- } \\
\text { Bluefarb } \\
\text { type }\end{array}$ & $\begin{array}{l}\text { Arteriovenous shunts (e.g., arteriovenous } \\
\text { malformation, iatrogenic arteriovenous fistula in } \\
\text { chronic hemodialysis) }\end{array}$ & \\
\hline
\end{tabular}

DDA, diffuse dermal angiomatosis. 